\title{
Phytochemical constituents, hypoglycemic and haematological effects of methanolic Acalypha wilkesiana leaves extract on streptozotocin-induced diabetic rats
}

\author{
Ayman Yahya El-Khateeb a, Nabil Abdel-Khalik Eid Azzaz b and Hemdan Ibrahem Mahmoud c,* \\ a Department of Agricultural Chemistry, Faculty of Agriculture, Mansoura University, Mansoura, 33516, Egypt \\ b Department of Agricultural Chemistry, Faculty of Agriculture, Damietta University, Damietta, 34517, Egypt \\ c Department of Agricultural Chemistry, Faculty of Agriculture, Minia University, Minia, 61517, Egypt \\ ${ }^{*}$ Corresponding author at: Department of Agricultural Chemistry, Faculty of Agriculture, Minia University, Minia, 61517, Egypt. \\ Tel.: +2.0115.1344411. Fax: +2.086.2362182.E-mail address: hemdanm@minia.edu.eg (H.I. Mahmoud).
}

\section{ARTICLE INFORMATION}

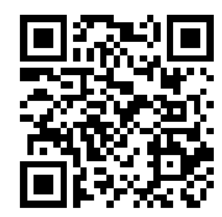

DOI: 10.5155 /eurjchem.5.3.430-438.1056

Received: 19 March 2014

Received in revised form: 12 April 2014

Accepted: 14 April 2014

Online: 30 September 2014

\section{KEYWORDS}

Lipid profile

Antidiabetic

Haematology

Liver functions

Kidney functions

Acalypha wilkesiana

\section{Introduction}

Diabetes mellitus is a group of metabolic diseases characterized by chronic hyperglycemia and disturbances in fat and protein metabolism due to deficiency of insulin secretion and/or action [1]. In addition to hyperglycemia, diabetes mellitus leads to long term multi-organ complications and causes damage to eye, heart, kidneys, nerves system and blood vessels [2]. Streptozotocin (STZ), an antibiotic produced by Streptomyces achromogenes, is the most widely used agent in experimental diabetes [3]. The main cause of streptozotocin induced $\beta$-cell death in the alkylation of DNA by nitrosourea moiety of this compound. However, reduction of nitric oxide and reactive oxygen species may also be involved in DNA fragmentation and other deleterious effect of streptozotocin such as increasing in serum level of lipid peroxide due to oxidation of cells [4].

Though different types of oral hypoglycemic agents are available along with insulin for the treatment of diabetes, there is an increase demand by patients to use the natural products with anti-diabetic activity [5]. Herbal products can improve glucose metabolism and the overall condition of individuals with diabetes, not only by hypoglycemic effects, but also by improving lipid metabolism, antioxidant status and capillary function [6]. Acalypha wilkesiana is one of a number of medicinal herbs that have potential for use in the management of diabetes mellitus. It is a member of the spurge family Euphorbiaceae and belongs to the genus Acalypha, comprising about 570 species. The plant has wide uses in the traditional medicines for the treatment of bacterial and fungal skin infections, neonatal jaundice, and gastrointestinal disorders [7]. Acalypha wilkesiana has been reported to possess antimicrobial [8], antihypertension [9] and anticarcinogenic properties [10]. It has also been reported by Udobang et al., [11] that the crude leaf extracts and fractions of this plant exhibit antiparasitic and analgesic properties. Though this plant is not edible, it is found to contain alkaloids, tannins and resins [12]. The chemical constituents of Acalypha wilkesiana leaves included acalyphamide, aurantiamide, succinimide calypho-lactate, 2-methyl anthraquinone, tri-o-methyl ellagic acid, $\beta$-sitosterol and $\beta$-Dglucoside [13]. Four kaempferol glycosides namely: mauritianin, clitorin, nicotiflorin and biorobin have also been isolated from the flowers and leaves of Acalypha wilkesiana [14]. Not much pharmacological research has been carried out on this plant despite its importance in traditional medicine. Therefore, the aim of this study is to examine the efficiency of 
methanolic leaves extract of Acalypha wilkesiana as hypoglycemic agent and some blood constituents within STZinduced diabetic rats.

\section{Experimental}

\subsection{Materials}

The present investigation was carried out using Acalypha wilkesiana leaves belong to family Euphorbiaceae. The samples collected from the experimental farm of the Faculty of Agriculture, Mansoura University, Mansoura, Egypt (April, 2013). Streptozotocin and methanol were purchased from Sigma Chemical Co. (St. Louis, MO, USA), while metformin hydrochloride was obtained from Chemical Industries Development (CID) for pharmaceutical industries, Giza, Egypt. All other chemicals were of the highest available commercial grade.

\subsection{Methods}

\subsubsection{Preparation of methanolic Acalypha wilkesiana leaves extract}

Acalypha wilkesiana leaves samples were air dried in the shade and ground into a fine powder, containing $11.65 \%$ moisture. Powdered air dried leaves $(1 \mathrm{Kg})$ were extracted by soaking at room temperature for six times with methanol $(20 \mathrm{~L})$. The methanolic extract was filtrated using Whatman filter paper (No. 1) and then concentrated to nearly dryness under reduced pressure by using the rotary evaporator at $45^{\circ} \mathrm{C}$ to achieve the crude methanolic extract which kept at $4{ }^{\circ} \mathrm{C}$ for further investigation and the percentage yield of the extract was $4.54 \%$ $(w: v)$.

\subsubsection{Analysis of polyphenols by HPLC technique}

Phenolic compounds of A. wilkesiana leaves extract were identified and quantified at the Central laboratory, National Research Center, Giza, Egypt, according to the method described by Goupy et al., [15] using reversed phase high performance liquid chromatography (RP-HPLC) with direct injection. Detection and quantification were performed with the help of the isocratic Varian system, equipped with Alltima column 5mm (C18, Hypersil MOS, $5 \mu \mathrm{m}, 200 \times 2.1 \mathrm{~mm}$, Hewlett Packard) $4.6 \times 250 \mathrm{~mm}$ and a detector namely Photo Diode Array (PDA) type. A gradient elution was employed using two solvent systems. Solvent A consisted of: acetic:water $(2: 98, v: v)$, solvent B: acetonitrile:water $(70: 30, v: v)$ with $1 \%$ of formic acid $(v: v)$. The solvent flow rate was $1 \mathrm{~mL} / \mathrm{min}$, volume of the injected sample was $10 \mu \mathrm{L}$ and separation was performed at 35 ${ }^{\circ} \mathrm{C}$. The amounts of phenolic compounds in the extract were assayed by external calibration curves, comparing their retention times with known standards (caffeic acid, $p$-coumaric acid, catechin and quercetin). For example, $100 \mathrm{mg}$ standard quercetin was taken into $100 \mathrm{~mL}$ volumetric flask, dissolved in the mobile phase and make up to the mark. The flask was shaken for $10 \mathrm{~min}$ and the volume was made up to the mark to obtain a standard stock solution of quercetin $(1000 \mu \mathrm{g} / \mathrm{mL})$. A stock solution was filtered through a $0.1 \mu \mathrm{m}$ membrane filter, and then the $10 \mathrm{ppm}$ working standard solution of quercetin was prepared. Suitable aliquots of stock solution were pipette out and volumes were made up to the mark with the mobile phase. To prepare a stock solution of sample, $1 \mathrm{~g}$ of accurately weighed methanolic Acalypha wilkesiana leaves extract were taken in a $100 \mathrm{~mL}$ volumetric flask, dissolved in the mobile phase and made up to the mark. After setting the instrument 10 $\mu \mathrm{L}$ of standard solution was injected and chromatogram recorded. From this, the area of chromatogram and the percentage of quercetin content were calculated at $280 \mathrm{~nm}$ and expressed as $\mathrm{mg} / 100 \mathrm{~g}$ dry matter.
2.2.3. Determination of antidiabetic activity of methanolic $A$. wilkesiana leaves extracts

\subsubsection{Experimental animals}

Male Sprague-Dawley albino rats, weighing 180-200 g were obtained from the animal house of Faculty of Pharmacy, Mansoura University, Egypt. The rats were kept for adaptation under normal laboratory conditions for 7 days before the beginning of the experiment. All rats were fed on a normal diet and allowed free access to water. After acclimatization, the rats were housed in metabolic cages and divided randomly into six groups having six animals in each group. Animal experimentation described in the study was strictly conducted in accordance with the guidelines prescribed by the University Ethical Committee.

Group 1, represents normal rats by means non diabetic, which were fed with normal diet and received saline solution for 30 days. The remaining rats were fasted for 24 hours, then intraperitoneally injected with streptozotocin freshly prepared in $0.10 \mathrm{M}$ citrate buffer, $\mathrm{pH}=4.5$ at a dose of $4.5 \mathrm{mg} / 100 \mathrm{~g}$ body weight (b. wt.) to induce diabetes mellitus, according to Ghasemi et al., [16]. In order to stave off the hypoglycaemia during the first day after the streptozotocin injection, diabetic rats were given $5 \%$ glucose solution orally as reported by Orhan et al., [17]. Blood glucose level of rats was determined 72 hours post-injection; rats were fasted for 18 hours before determination. Rats with blood glucose levels over $300 \mathrm{mg} / \mathrm{dL}$ were considered sufficiently as streptozotocin-diabetic rats and ready for treating with the extract. Then, diabetic rats were randomly divided into 5 groups (6 rats for each). Group 2 , represents diabetic control rats, received a normal diet for 30 days without any treatment. Group 3, represents diabetic rats treated with metformin hydrochloride powder as a reference drug in dose $50 \mathrm{mg} / 100 \mathrm{~g} \mathrm{~b}$. wt. Groups 4, 5 and 6 were diabetic rats administered with crude methanolic Acalypha wilkesiana leaves extract in doses of 10,20 and $40 \mathrm{mg} / 100 \mathrm{~g}$ b. wt. respectively. Reference drug and crude methanolic extract were dissolved in saline solution (Sodium chloride, 0.9\%) and given orally by a stomach tube after fasting for 2 hours, daily for 30 days.

Blood samples were collected from the eye canthus by heparinized tubes every 10 days after the beginning of the experiment. Then, each blood sample was divided into two portions. Centrifugation was carried out to a first portion to obtain clear serum and the fasting serum glucose levels were determined immediately. Serum blood samples were kept at refrigerator under freezing conditions for the determination of the other parameters included liver functions (ALT and AST), kidney functions (creatinine and urea) and lipid profile (Triglycerides, total cholesterol, HDL-C, LDL-C and VLDL-C). The second portion was treated with $10 \%$ of ethylene diamine tetracetic acid (EDTA) with a good shaking to determine the complete blood count (CBC) as a haematological analysis.

\subsubsection{Chemical analysis of blood}

Serum glucose was determined by a colorimetric enzymatic method glucose oxidase (GOD) described in commercial kits by Spinreact (Spain) according to Trinder [18]. Liver functions (ALT and AST) were determined as described in commercial kits by Randox (United Kingdom) according to the method of Reitman and Frankel [19]. Kidney functions (Serum creatinine and urea) were determined by a colorimetric method according to Larsen [20]; Fawcett and Scott [21], respectively, as described in commercial kits by Human (Germany). The lipid profile, triglycerides (TG), total cholesterol (TC) and high density lipoprotein cholesterol (HDL-C) were determined by enzymatic colorimetric method of [22-24] described in a commercial kits by Human (Germany). 
Table 1. HPLC analysis of polyphenols of methanolic Acalypha wilkesiana leaves extract

\begin{tabular}{llll}
\hline Compound & Concentration $\mathbf{~ ( m g / 1 0 0 ~ g ) ~}$ & Compound & Concentration (mg/100 g) \\
\hline Apigenin & 624.15 & Caffeic acid & 94.03 \\
Caffeine & 33.78 & Catechin & 890.66 \\
Catechol & 32.21 & Chlorogenic acid & 62.61 \\
Chrysin & - & Cinnamic acid & 522.36 \\
Coumarin & 29.16 & Ellagic acid & 11.70 \\
Ferulic acid & 139.27 & Gallic acid & 227.16 \\
Hisperidin & - & Kampferol & 10.55 \\
Luteolin & 137.52 & Naringenin & 31.24 \\
$p$-Coumaric acid & 42.76 & p-OH-Benzoic acid & 128.16 \\
Protocatechouic & 44.18 & Pyrogallol & 9.15 \\
Quercetin & 311.25 & Rosmarinic acid & - \\
Rutin & 95.74 & Salicylic acid & - \\
Syringic acid & 32.62 & Vanillic acid & \\
\hline
\end{tabular}

Serum low density lipoprotein cholesterol (LDL-C) and very low density lipoprotein cholesterol (VLDL-C) concentrations were calculated using the Friedewald [25] equations as follows:

VLDL-C $=\mathrm{TG} / 5$

LDL-C $=$ TC $-(H D L-C+V L D L-C)$

The atherogenic indices were calculated as reported by Ikewuchi and Ikewuchi [26] using the following equations:

Cardiac risk ratio $=\frac{\mathrm{TC}}{\mathrm{HDLC}}$

Atherogenic coefficient $=\frac{[\text { TC }-(\text { HDLc })]}{[\text { HDLc }]}$

Atherogenic index of plasma $=\log \frac{\mathrm{TG}}{\mathrm{HDLC}}$

\subsubsection{Haematological analysis}

All haematological tests were made using apparatus namely ABX Micros 60 which a fully automated hematology analyzer from Sysmex Corporation international company [27]. Micros 60 is an ideal choice for the determination of up to 18 fully automated parameters including hemoglobin $(\mathrm{Hb})$, red blood cells count (RBC), hematocrit (Hct), packed cell volume (PCV), mean corpuscular volume (MCV), mean corpuscular hemoglobin $(\mathrm{MCH})$, mean corpuscular hemoglobin concentration (MCHC), red cell distribution width (RDW), platelets count (Plt), platelets hematocrit (PCT), mean platelet volume (MPV), platelet distribution width (PDW), white blood cells count (WBC) and WBC differential: Lymphocytes (LYM), Monocytes (MON) and Granulocytes (GRA). It can perform 60 samples per hour in open or closed tube forms for sample volume of $10 \mu \mathrm{L}$ of whole blood per cycle.

\subsubsection{Statistical analysis}

Statistical analyses for obtained data were done using the SPSS statistical software package. All comparisons were first subjected to one way analysis of variance (ANOVA) and significant differences between treatment means were determined using Duncan's multiple rang test at $\mathrm{p}<0.05$ as the level of the significance.

\section{Results and discussion}

\subsection{Analysis of polyphenols by HPLC}

High performance liquid chromatography procedure was used for qualitative and quantitative analysis of polyphenolic compounds in methanolic Acalypha wilkesiana leaves extract. Twenty six polyphenolic compounds were available as authentic samples namely: apigenin, caffeine, catechol, chrysin, coumarin, ferulic acid, hisperidin, luteolin, $p$-coumaric acid, protocatechouic, quercetin, rutin, syringic acid, caffeic acid, catechin, chlorogenic acid, cinnamic acid, ellagic acid, gallic acid, kampferol, naringenin, $p$-OH-benzoic acid, pyrogallol, rosmarinic acid, salicylic acid and vanillic acid were used to identify the corresponding components in Acalypha wilkesiana leaves extract polyphenols.

Data in Table 1 reveal that twenty one compounds with different retention times were recognized in HPLC chromatogram. From the same table, it could be noticed that catechin, apigenin, ellagic acid, quercetin and kampferol were the predominant indentified component in Acalypha wilkesiana leaves extract as percentages of 29.91, 20.96, 17.54, 10.45 and $7.63 \%$, respectively. Followed by ferulic acid (4.67\%), luteolin $(4.61 \%)$, pyrogallol $(4.30 \%)$, rutin $(3.21 \%)$, caffeic acid $(3.15 \%)$, chlorogenic acid $(2.10 \%)$, protocatechouic acid (1.48\%), $p$-coumaric acid $(1.43 \%)$, caffiene $(1.13 \%)$, syrigic acid (1.09\%), catechol (1.08\%) and $p$-OH-benzoic acid (1.05\%), in addition to traces of coumarin, gallic acid, naringenin and rosemarinic acid. While, five polyphenolic compounds, namely: chrysin, hisperidin, cinnamic acid, salicylic acid and vanillic acid were absence in the methanolic leaves extract of Acalypha wilkesiana.

Ours results were agreed with those obtained by Ikewuchi et al., [28] who detected twenty nine known flavonoids in aqueous Acalypha wilkesiana leaves extract, consisting mainly of apigenin, quercetin, naringenin, kaempferol, epicatechin, catechin, ellagic acid, butein, myricetin, biochanin, baicalein, gallocatechin, robinetin, silymarin, and epigallocatechin 29.77, $14.97,11.12,10.62,9.05,4.37,2.36,2.34,2.25,2.08,1.76,1.72$, $1.14,1.13$ and $1.11 \%$, respectively. However, the preliminary phytochemical screening of the methanolic $A$. wilkesiana leaves extract revealed the presence of alkaloids, flavonoids (catechins and flavones), saponins and tannins (Table 1), all of which have potential health promoting effects, at least under some circumstances [29].

\subsection{Effect of crude methanolic of Acalypha wilkesiana leaves extracts on blood glucose level}

The obtained data in Table 2 indicate that the injection of streptozotocin at the dose $4.5 \mathrm{mg} / 100 \mathrm{~g}$ body weight caused a highly significant $(\mathrm{p}<0.05)$ increase in blood glucose level from 102 to $387 \mathrm{mg} / \mathrm{dL}$ for non-diabetic and diabetic rats at zero time, respectively. In addition, gradual increasing was observed during the experimental periods (10,20 and 30 days) until reaching the maximum level of $464 \mathrm{mg} / \mathrm{dL}$ for diabetic rats at the end of the experiment. This increase may be due to the destructive effect of streptozotocin on $\beta$-cells of islets of Langerhans which lead to insulin deficiency. 
Table 2. Effect of crude methanolic leaves extract of Acalypha wilkesiana on levels of blood glucose (mg/dL) in diabetic rats.

\begin{tabular}{|c|c|c|c|c|c|c|}
\hline \multirow{2}{*}{$\begin{array}{l}\text { Treatment } \\
\text { period }\end{array}$} & \multirow{2}{*}{$\begin{array}{l}\text { Normal } \\
\text { control }\end{array}$} & \multirow{2}{*}{$\begin{array}{l}\text { Diabetic } \\
\text { Control }\end{array}$} & \multirow{2}{*}{$\begin{array}{l}\text { Diabetic + } \\
\text { metformin }\end{array}$} & \multicolumn{3}{|c|}{ Diabetic $+A$. wilkesiana extract at a dose } \\
\hline & & & & $10 \mathrm{mg} / 100 \mathrm{~g}$ b. wt. & $20 \mathrm{mg} / 100 \mathrm{~g}$ b. wt. & $40 \mathrm{mg} / 100 \mathrm{~g}$ b. wt. \\
\hline Zero time & $102 \pm 3.75$ & $387 \pm 14.08^{a}$ & $300 \pm 12.96^{\mathrm{a}, \mathrm{b}}$ & $390 \pm 6.42^{\text {a }}$ & $388 \pm 15.22$ a & $378 \pm 11.03$ a \\
\hline 10 days & $104 \pm 3.87$ & $400 \pm 11.42^{\mathrm{a}}$ & $230 \pm 6.92 \mathrm{a}, \mathrm{b}$ & $355 \pm 13.46^{a, b, c}$ & $300 \pm 9.42 \mathrm{a}, \mathrm{b}, \mathrm{c}$ & $281 \pm 13.76^{a, b, c}$ \\
\hline 20 days & $99 \pm 2.65$ & $428 \pm 16.42$ a & $151 \pm 4.42 \mathrm{a}, \mathrm{b}$ & $298 \pm 15.99$ a,b,c & $229 \pm 6.42^{a, b, c}$ & $169 \pm 6.42^{a, b, c}$ \\
\hline 30 days & $103 \pm 2.05$ & $464 \pm 20.20^{a}$ & $109 \pm 3.15 b$ & $183 \pm 4.13 \mathrm{a}, \mathrm{b}, \mathrm{c}$ & $120 \pm 7.01^{\mathrm{a}, \mathrm{b}, \mathrm{c}}$ & $105 \pm 4.66^{b}$ \\
\hline
\end{tabular}

a The values are mean \pm SD of 6 rats in each group, significantly different from normal control at $p<0.05$.

$\mathrm{b}$ The values are mean \pm SD of 6 rats in each group, significantly different from diabetic control at $\mathrm{p}<0.05$.

c The values are mean \pm SD of 6 rats in each group, significantly different from diabetic + metformin at $\mathrm{p}<0.05$.

Table 3. Effect of crude methanolic Acalypha wilkesiana leaves extract on liver functions (IU/L) activities in diabetic rats *.

\begin{tabular}{|c|c|c|c|c|c|c|c|}
\hline \multirow{2}{*}{$\begin{array}{l}\text { Liver functions } \\
\text { (IU/L) }\end{array}$} & \multirow{2}{*}{$\begin{array}{l}\text { Treatment } \\
\text { period }\end{array}$} & \multirow{2}{*}{$\begin{array}{l}\text { Normal } \\
\text { control }\end{array}$} & \multirow{2}{*}{$\begin{array}{l}\text { Diabetic } \\
\text { control }\end{array}$} & \multirow{2}{*}{$\begin{array}{l}\text { Diabetic + } \\
\text { metformin }\end{array}$} & \multicolumn{3}{|c|}{ Diabetic $+A$. wilkesiana extract at a dose } \\
\hline & & & & & $10 \mathrm{mg} / 100 \mathrm{~g}$ b. wt & $20 \mathrm{mg} / 100 \mathrm{~g}$ b. wt & $40 \mathrm{mg} / 100 \mathrm{~g}$ b. wt \\
\hline \multirow[t]{2}{*}{ ALT } & Zero time & $26 \pm 2.96$ & $49 \pm 4.44^{a}$ & $51 \pm 3.26^{\mathrm{a}, \mathrm{b}}$ & $47 \pm 4.71 \mathrm{a}, \mathrm{b}, \mathrm{c}$ & $49 \pm 3.22 \mathrm{a}, \mathrm{b}, \mathrm{c}$ & $48 \pm 3.84 \mathrm{a}, \mathrm{b}, \mathrm{c}$ \\
\hline & 30 days & $27 \pm 1.16$ & $71 \pm 5.09 \mathrm{a}$ & $34 \pm 4.11 \mathrm{a}, \mathrm{b}$ & $33 \pm 4.25 \mathrm{a}, \mathrm{b}$ & $27 \pm 2.57 \mathrm{~b}, \mathrm{c}$ & $26 \pm 3.02 b, c$ \\
\hline \multirow[t]{2}{*}{$\overline{\mathrm{AST}}$} & Zero time & $34 \pm 2.11$ & $54 \pm 6.06^{a}$ & $61 \pm 5.72 \mathrm{a}, \mathrm{b}$ & $64 \pm 5.12 \mathrm{a}, \mathrm{b}$ & $57 \pm 4.65 a, b$ & $53 \pm 5.04$ a \\
\hline & 30 days & $40 \pm 4.13$ & $84 \pm 8.14$ a & $47 \pm 3.55 \mathrm{a}, \mathrm{b}$ & $53 \pm 4.41 \mathrm{a}, \mathrm{b}, \mathrm{c}$ & $41 \pm 4.89 \mathrm{~b}, \mathrm{c}$ & $31 \pm 1.37 \mathrm{a}, \mathrm{b}, \mathrm{c}$ \\
\hline
\end{tabular}

* The values are mean \pm SD of 6 rats in each group.

a Significantly different from normal control at $\mathrm{p}<0.05$.

b Significantly different from diabetic control at $\mathrm{p}<0.05$.

c Significantly different from diabetic+metformin at $\mathrm{p}<0.05$.

Moreover, the absence of available insulin in blood circulation, these may be the main causes of hyperglycemia, which observed in the treated rats with streptozotocin as achieved by Vessal et al., [4]. Also, Lenzen [30] reported that the significant increase in the levels of blood glucose in STZinduced diabetic rats could be due to a beta cytotoxic induces chemical diabetes through damaging insulin-secreting cells.

It could be reported that the most effective dose of reducing blood glucose level was demonstrated at $40 \mathrm{mg} / 100 \mathrm{~g}$ b. wt. which decreased this parameter to $105 \mathrm{mg} / \mathrm{dL}$ after 30 days, where the maximum reduction of about $77.50 \%$ was obtained compared with diabetic control rats. While, treated rats with metformin $\mathrm{HCl}$ achieved a $76.50 \%$, reducing blood glucose level at the dose $50 \mathrm{mg} / 100 \mathrm{~g} \mathrm{~b}$. wt. after 30 days. The initial antihyperglycemic activity was observed after ten days, then the blood glucose level gradually decreased for all groups during the experimental periods. The methanolic A. wilkesiana leaves extract at doses 10,20 and $40 \mathrm{mg} / 100 \mathrm{~g} \mathrm{~b}$. wt. reduced blood glucose levels by 11,25 and $30 \%$, respectively, comparing with that observed in diabetic control rats after 10 days (Table 2). Our data were in accordance with those obtained by Ikewuchi et al., [28] who used 10, 20 and 30 $\mathrm{mg} / 100 \mathrm{~g}$ b. wt. of aqueous $A$. wilkesiana leaves extract, which decreased blood glucose levels by 8.20, 20.86 and $21.34 \%$, respectively, compared with untreated diabetic rats after 10 days. Additionally, our results run parallel with those obtained by Al-Attar [31] who illustrated $11.6 \%$ as a reduced percentage of blood glucose level by using aqueous $A$. wilkesiana leaves extract in diabetic mice after 30 days. Furthermore, Odoh et al., [32] showed that the most significant reduction of fasting blood glucose level (48.36\%) was observed for $200 \mathrm{mg} / \mathrm{kg} \mathrm{b.} \mathrm{wt.} \mathrm{of}$ methanolic A. wilkesiana root extract in alloxan-induced diabetic rats. Moreover, these previous comparisons demonstrated that hypoglycemic activity of the methanolic $A$. wilkesiana leaves extract was more effective than the aqueous ones at the same experimental period. Also, the higher percentage reduction in blood glucose levels, produced by the extract in this study, supports the use of $A$. wilkesiana leaves in the management of diabetes mellitus.

Several studies reported that the A. wilkesiana leaves contain polyphenols as bioactive compounds such as querecetin which produces an increase in the number of pancreatic islet cells, probably increase insulin release in STZdiabetic rats and induces the hepatic glucokinase enzyme. Thus, the lowering property of plasma glucose could also be attributed to the ability of querecetin to regenerate pancreatic $\beta$-cells and to increase insulin release [4]. Finally, it could be concluded that lowering blood glucose levels, which was observed in the diabetic animals may be due to the stimulation of $\beta$-cells of pancreatic islets and mediated through stimulation of insulin release resembling the oral hypoglycemic drugs or peripheral glucose utilization [33].

\subsection{Effect of crude methanolic extracts of Acalypha wilkesiana leaves on liver functions}

Alanine amino transferase (ALT) and aspartate amino transferase (AST) activities are known as cytosolic marker enzymes reflecting hepatocellular necrosis as they are released into the blood after damaging of the cell membrane; therefore both enzymes are used as indicators for hepatic damage [34]. Liver functions during this investigation were examined through the determination of ALT and AST activities in serum of non-diabetic and STZ-diabetic rats. It is clear that ALT and AST increased significantly from 26 and $34 \mathrm{IU} / \mathrm{L}$ in non-diabetic rats to 49 and $63 \mathrm{IU} / \mathrm{L}$, respectively in diabetic control rats (Table 3). Such a significant increase of ALT and AST activities as shown suggest the possible necrotic injury of the liver or cholestasis with hepatocellular necrosis [35].

Data in Table 3 clearly indicate no significance differences between normal and treated rats with the methanolic leaves extract of $A$. wilkesiana at both doses 20 and $40 \mathrm{mg} / 100 \mathrm{~g} \mathrm{~b}$. wt. for ALT activity values at the end of the experimental period. In addition, AST activity value differences were not significant between normal control and treated rats with A. wilkesiana leaves extract at dose $20 \mathrm{mg} / 100 \mathrm{~g}$ b. wt. after 30 days. From the same table, it could be observed that treatment with methanolic $A$. wilkesiana leaves extract in all doses was more effective for gradually reducing of ALT and AST levels than treated diabetic rats with metformin $\mathrm{HCl}$.

Our results for ALT levels were more effectual than those obtained by Ikewuchi et al., [28] who found no significant differences between untreated diabetic and diabetic rats treated with aqueous $A$. wilkesiana leaves extract. Furthermore, methanolic $A$. wilkesiana leaves extract reduced AST values to about $63 \%$ compared with Ikewuchi et al., [28] who offered a lower reduction value of $33 \%$ using an aqueous extract at the end of the experimental period. The restoration of AST and ALT activities to their respective normal levels after supplementation of methanolic leaves extract of $A$. wilkesiana further strengthens the antidiabetogenic effect of this extract. Moreover, it has been concluded that the decrease in the serum transaminase enzymes in STZ-induced diabetic rats by $A$. wilkesiana leaves extract may be due to the prevention of the leakage of intracellular enzymes by its membrane stabilizing activity. 
Table 4. Effect of crude methanolic Acalypha wilkesiana leaves extract on kidney functions (mg/dL) levels in diabetic rats*.

\begin{tabular}{|c|c|c|c|c|c|c|c|}
\hline \multirow{2}{*}{$\begin{array}{l}\text { Kidney functions } \\
\text { (mg/dL) }\end{array}$} & \multirow{2}{*}{$\begin{array}{l}\text { Treatment } \\
\text { period }\end{array}$} & \multirow{2}{*}{$\begin{array}{l}\text { Normal } \\
\text { control }\end{array}$} & \multirow{2}{*}{$\begin{array}{l}\text { Diabetic } \\
\text { control }\end{array}$} & \multirow{2}{*}{$\begin{array}{l}\text { Diabetic + } \\
\text { metformin }\end{array}$} & \multicolumn{3}{|c|}{ Diabetic $+A$. wilkesiana extract at a dose } \\
\hline & & & & & $10 \mathrm{mg} / 100 \mathrm{~g} b . \mathrm{wt}$ & $20 \mathrm{mg} / 100 \mathrm{~g}$ b. wt & $40 \mathrm{mg} / 100 \mathrm{~g}$ b. wt \\
\hline \multirow[t]{2}{*}{ Creatinine } & Zero time & $1.3 \pm 0.05$ & $1.6 \pm 0.03$ & $1.9 \pm 0.02$ & $1.5 \pm 0.07$ & $1.4 \pm 0.05$ & $1.6 \pm 0.02$ \\
\hline & 30 days & $1.2 \pm 0.01$ & $2.3 \pm 0.08$ & $1.4 \pm 0.01$ & $1.1 \pm 0.02$ & $1.2 \pm 0.03$ & $1.0 \pm 0.02$ \\
\hline \multirow[t]{2}{*}{ Urea } & Zero time & $51 \pm 2.03$ & $77 \pm 2.31$ a & $72 \pm 1.56 \mathrm{a}, \mathrm{b}$ & $70 \pm 1.15 \mathrm{a}, \mathrm{b}$ & $70 \pm 1.77 \mathrm{a}, \mathrm{b}$ & $71 \pm 2.72 \mathrm{a}, \mathrm{b}$ \\
\hline & 30 days & $55 \pm 1.45$ & $99 \pm 3.11$ a & $69 \pm 2.08 \mathrm{a}, \mathrm{b}$ & $73 \pm 3.20 \mathrm{a}, \mathrm{b}$ & $61 \pm 1.66 \mathrm{a}, \mathrm{b}, \mathrm{c}$ & $52 \pm 1.48$ b,c \\
\hline
\end{tabular}

* The values are mean \pm SD of 6 rats in each group.

a Significantly different from normal control at $\mathrm{p}<0.05$.

b Significantly different from diabetic control at $\mathrm{p}<0.05$.

c Significantly different from diabetic+metformin at $\mathrm{p}<0.05$.

Table 5. Effect of crude methanolic leaves extract of Acalypha wilkesiana on lipid profile (mg/dL) levels in diabetic rats *.

\begin{tabular}{|c|c|c|c|c|c|c|c|}
\hline \multirow{2}{*}{$\begin{array}{l}\text { Lipid profile } \\
\text { (mg/dL) }\end{array}$} & \multirow{2}{*}{$\begin{array}{l}\text { Treatment } \\
\text { period }\end{array}$} & \multirow{2}{*}{$\begin{array}{l}\text { Normal } \\
\text { control }\end{array}$} & \multirow{2}{*}{$\begin{array}{l}\text { Diabetic } \\
\text { control }\end{array}$} & \multirow{2}{*}{$\begin{array}{l}\text { Diabetic + } \\
\text { metformin }\end{array}$} & \multicolumn{3}{|c|}{ Diabetic $+A$. wilkesiana extract at a dose } \\
\hline & & & & & $10 \mathrm{mg} / 100 \mathrm{~g}$ b. wt & $20 \mathrm{mg} / 100 \mathrm{~g}$ b. wt & $40 \mathrm{mg} / 100 \mathrm{~g} \mathrm{b.} \mathrm{wt}$ \\
\hline \multirow[t]{2}{*}{ Triglycerides } & Zero time & $171 \pm 3.67$ & $289 \pm 11.45^{\mathrm{a}}$ & $280 \pm 8.20$ a,b & $276 \pm 7.33 \mathrm{a}, \mathrm{b}$ & $280 \pm 6.38^{a, b}$ & $28 \pm 8.33^{a, b}$ \\
\hline & 30 days & $168 \pm 5.15$ & $301 \pm 9.78^{a}$ & $188 \pm 9.64 \mathrm{a}, \mathrm{b}$ & $205 \pm 6.21 \mathrm{a}, \mathrm{b}, \mathrm{c}$ & $183 \pm 4.05 a, b, c$ & $171 \pm 6.96 \mathrm{~b}, \mathrm{c}$ \\
\hline \multirow[t]{2}{*}{ Total cholesterol } & Zero time & $195 \pm 4.04$ & $380 \pm 9.85^{\text {a }}$ & $377 \pm 9.72^{a}$ & $383 \pm 7.13 \mathrm{a}, \mathrm{c}$ & $375 \pm 5.74 a, b, c$ & $386 \pm 8.88$ a,b,c \\
\hline & 30 days & $199 \pm 6.51$ & $408 \pm 12.55^{\mathrm{a}}$ & $200 \pm 7.51^{\mathrm{a}, \mathrm{b}}$ & $301 \pm 5.45 \mathrm{a}, \mathrm{b}, \mathrm{c}, \mathrm{f}$ & $210 \pm 4.42 \mathrm{a}, \mathrm{b}, \mathrm{c}$ & $190 \pm 3.91 \mathrm{a}, \mathrm{b}, \mathrm{c}$ \\
\hline \multirow[t]{2}{*}{$\overline{\mathrm{HDL}-\mathrm{C}}$} & Zero time & $47 \pm 1.76$ & $26 \pm 2.16^{a}$ & $28 \pm 3.11 \mathrm{a}, \mathrm{b}$ & $29 \pm 2.60 \mathrm{a}, \mathrm{b}$ & $30 \pm 2.88^{a, b}$ & $29 \pm 4.01^{\mathrm{a}, \mathrm{b}}$ \\
\hline & 30 days & $39 \pm 1.45$ & $23 \pm 4.33$ a & $40 \pm 3.96 \mathrm{~b}$ & $32 \pm 3.84 a, b, c$ & $48 \pm 4.36 \mathrm{a}, \mathrm{b}, \mathrm{c}$ & $43 \pm 4.55 \mathrm{a}, \mathrm{c}$ \\
\hline \multirow[t]{2}{*}{ LDL-C } & Zero time & $114 \pm 2.60$ & $296 \pm 3.10^{a}$ & $293 \pm 2.67 \mathrm{a}$ & $299 \pm 3.04 \mathrm{a}, \mathrm{c}$ & $289 \pm 3.44 a, b, c$ & $301 \pm 4.20$ a,b,c \\
\hline & 30 days & $126 \pm 1.36$ & $325 \pm 5.26^{a}$ & $122 \pm 2.96^{b}$ & $228 \pm 5.11 \mathrm{a}, \mathrm{b}, \mathrm{c}$ & $125 \pm 2.85 \mathrm{~b}, \mathrm{c}$ & $113 \pm 3.71 \mathrm{a}, \mathrm{b}, \mathrm{c}$ \\
\hline \multirow[t]{2}{*}{ VLDL-C } & Zero time & $34 \pm 0.66$ & $58 \pm 1.11$ a & $56 \pm 0.85$ a & $55 \pm 1.12$ a & $56 \pm 0.55$ a & $56 \pm 1.97$ a \\
\hline & 30 days & $34 \pm 0.35$ & $60 \pm 0.99$ a & $38 \pm 0.77 \mathrm{a}, \mathrm{b}$ & $41 \pm 1.08 \mathrm{a}, \mathrm{b}$ & $37 \pm 0.64$ b & $34 \pm 1.04 \mathrm{~b}, \mathrm{c}$ \\
\hline
\end{tabular}

* The values are mean \pm SD of 6 rats in each group.

a Significantly different from normal control at $\mathrm{p}<0.05$.

b Significantly different from diabetic control at $\mathrm{p}<0.05$.

c Significantly different from diabetic+metformin at $\mathrm{p}<0.05$.

\subsection{Effect of crude methanolic Acalypha wilkesiana leaves extracts on kidney functions}

Determination of serum creatinine and urea were used as indicators for kidney functions. The effect of methanolic $A$. wilkesiana leaves extract on serum creatinine and urea levels in STZ-diabetic rats is illustrated in Table 4. It could be noticed that injection with streptozocin induced a significant increase in serum creatinine and urea levels from 1.3 and 51.0 to 1.6 and $77.0 \mathrm{mg} / \mathrm{dL}$ respectively, compared with non-diabetic rats at the beginning of the experiment. These elevations may be attributed to the diverse hormonal and metabolic changes that accompany diabetes and the toxic effect of streptozocin on kidney [36]. It could be perceived from Table 4 that no significance differences between normal and treated rats with the methanolic extract at doses 10, 20 and $40 \mathrm{mg} / 100 \mathrm{~g} \mathrm{~b}$. wt. for creatinine levels at the end of the experimental period. On the other hand, serum urea values were decreased with increasing the concentration of methanolic extract and the period of experiment to reach $52 \mathrm{mg} / \mathrm{dL}$ as a non significant value at the dose $40 \mathrm{mg} / 100 \mathrm{~b}$. wt. compared with normal rats at the end of the experimental period.

Data in Table 4 show that methanolic A. wilkesiana leaves extract at doses 10, 20 and $40 \mathrm{mg} / 100 \mathrm{~g} \mathrm{b.} \mathrm{wt.} \mathrm{reduced} \mathrm{serum}$ urea levels to $26.3,38.4$ and $47.5 \%$, respectively, after 30 days of the experiment comparing with diabetic control rats. Previous results run parallel with those of Ikewuchi et al., [28] who established that the reduction of blood urea represents $33.4,47.8$ and $56.5 \%$ at doses 10, 20 and $30 \mathrm{mg} / 100 \mathrm{~g} \mathrm{~b}$. wt. respectively of aqueous $A$. wilkesiana leaves extract at the end of the experimental period. The improvement of the kidney functions associated with treating the diabetic rats with the methanolic leaves extract of $A$. wilkesiana could be attributed to its antidiabetic action resulting in alleviation of altered metabolic status in animals and to its potent antioxidant potential which have scavenge free radicals and thereby may protect renal cells from oxidative stress.

\subsection{Effect of crude methanolic Acalypha wilkesiana leaves extracts on lipid profile}

Recorded data in Table 5 reveal that serum triglyceride, total cholesterol, LDL-C and VLDL-C values increased from 171, 195, 114 and 34 in non-diabetic rats to 289, 380, 296 and 58 $\mathrm{mg} / \mathrm{dL}$, respectively in diabetic rats by injection with streptozocin. On the other hand, Table 5 declares that there is a highly significant decrease in serum HDL-C level since it reached $26 \mathrm{mg} / \mathrm{dL}$ for STZ-diabetic rats, comparing with 47 $\mathrm{mg} / \mathrm{dL}$ for normal rats at the beginning of the experiment. Many compositional abnormalities in the lipoproteins have been found in diabetic patients and the major cause of hypertriglyceridemia appeared to be the overproduction of VLDL, which is attributed to hyperglycemia and/or increased influx of free fatty acids in the liver [37]. Also, Fernandez et al., [38] suggested that increasing in LDL cholesterol level (the risk factor for cardiovascular disease) may be attributed to some reasons such as an increase of intestinal absorption of lipid, cholesterol synthesis and liver lipid synthesis or liver dysfunction. In addition, the decrease in the serum HDL level may be due to the decrease of lecithin cholesterol acetyl transferase which responsible for estrification of cholesterol in HDL.

It could be noticed, from Table 5 that triglyceride decreased with increasing the extract concentration and the experimental period. Accordingly, the treatment of diabetic rats with 40 $\mathrm{mg} / 100 \mathrm{~g} \mathrm{~b}$. wt. of methanolic A. wilkesiana leaves extract was the most effective concentration, where the reduction percentage of triglyceride level achieves about $43 \%$ at the end of the experiment compared with diabetic control rats. These findings were in the same line of those reported by Ikewuchi $e t$ al., [28] who conducted that triglycerides value were reduced in percentages of 10,14 and $24 \%$ by using the doses 10,20 and $30 \mathrm{mg} / 100 \mathrm{~g}$ b. wt. respectively, of aqueous $A$. wilkesiana leaves extract. Data presented in Table 5 show that the administration of diabetic rats with $40 \mathrm{mg} / 100 \mathrm{~g}$ b. wt. of methanolic $A$. wilkesiana leaves extract for 30 days led to the highest reducing effect of total cholesterol level, which reached $190 \mathrm{mg} / \mathrm{dL}$ with a reduced percentage of $53 \%$ comparing with untreated diabetic rats. On the contrary, It has been reported that aqueous $A$. wilkesiana leaves extract have a low effect in reducing total cholesterol levels, which accomplished 4, 4 and $19 \%$ by using the doses 10,20 and $30 \mathrm{mg} / 100 \mathrm{~g} \mathrm{~b}$. wt., respectively [28]. 
Table 6. Effect of crude methanolic leaves extract of Acalypha wilkesiana on atherogenic indices in diabetic rats*.

\begin{tabular}{|c|c|c|c|c|c|c|c|}
\hline \multirow{2}{*}{$\begin{array}{l}\text { Atherogenic } \\
\text { indices }\end{array}$} & \multirow{2}{*}{$\begin{array}{l}\text { Treatment } \\
\text { period }\end{array}$} & \multirow{2}{*}{$\begin{array}{l}\text { Normal } \\
\text { control }\end{array}$} & \multirow{2}{*}{$\begin{array}{l}\text { Diabetic } \\
\text { control }\end{array}$} & \multirow{2}{*}{$\begin{array}{l}\text { Diabetic + } \\
\text { metformin }\end{array}$} & \multicolumn{3}{|c|}{ Diabetic $+A$. wilkesiana extract at a dose } \\
\hline & & & & & $10 \mathrm{mg} / 100 \mathrm{~g} \mathrm{~b} . \mathrm{wt}$ & $20 \mathrm{mg} / 100 \mathrm{~g}$ b. wt & $40 \mathrm{mg} / 100 \mathrm{~g} \mathrm{~b} . \mathrm{wt}$ \\
\hline \multirow{2}{*}{$\begin{array}{l}\text { Cardiac risk } \\
\text { ratio } \\
\end{array}$} & Zero time & $4.15 \pm 0.27$ & $14.62 \pm 0.66^{a}$ & $13.46 \pm 0.54^{\mathrm{a}}$ & $13.21 \pm 0.38^{\mathrm{a}}$ & $12.50 \pm 0.75^{\text {a }}$ & $13.31 \pm 0.35^{\mathrm{a}}$ \\
\hline & 30 days & $5.10 \pm 0.17$ & $17.74 \pm 0.43 \mathrm{a}$ & $5.00 \pm 0.14 \mathrm{a}, \mathrm{b}$ & $9.41 \pm 0.27 \mathrm{a}, \mathrm{b}, \mathrm{c}$ & $4.38 \pm 0.11 b$ & $4.42 \pm 0.13 b$ \\
\hline \multirow{2}{*}{$\begin{array}{l}\text { Atherogenic } \\
\text { coefficient }\end{array}$} & Zero time & $3.15 \pm 0.11$ & $13.62 \pm 0.46^{a}$ & $12.46 \pm 0.32^{a}$ & $12.21 \pm 0.41^{\mathrm{a}}$ & $11.50 \pm 0.29 \mathrm{a}$ & $12.31 \pm 0.36^{\mathrm{a}}$ \\
\hline & 30 days & $4.10 \pm 0.27$ & $16.74 \pm 0.58{ }^{a}$ & $4.00 \pm 0.27 \mathrm{a}, \mathrm{b}$ & $8.41 \pm 0.27 \mathrm{a}, \mathrm{b}, \mathrm{c}$ & $3.38 \pm 0.27 \mathrm{~b}, \mathrm{c}$ & $3.42 \pm 0.27 b, c$ \\
\hline \multirow{2}{*}{$\begin{array}{l}\text { Atherogenic } \\
\text { index of } \\
\text { plasma }\end{array}$} & Zero time & $0.56 \pm 0.04$ & $1.05 \pm 0.11$ & $1.00 \pm 0.07$ & $0.98 \pm 0.06$ & $0.97 \pm 0.08$ & $0.99 \pm 0.07$ \\
\hline & 30 days & $0.63 \pm 0.03$ & $1.12 \pm 0.12$ & $0.67 \pm 0.04$ & $0.81 \pm 0.05$ & $0.58 \pm 0.02$ & $0.60 \pm 0.02$ \\
\hline
\end{tabular}

* The values are mean \pm SD of 6 rats in each group.

a Significantly different from normal control at $\mathrm{p}<0.05$.

b Significantly different from diabetic control at $\mathrm{p}<0.05$.

c Significantly different from diabetic+metformin at $\mathrm{p}<0.05$.

Table 7. Effect of treatment of crude methanol leaves extract of Acalypha wilkesiana on levels of $\mathrm{Hb}(\mathrm{g} / \mathrm{dL}$ ) in diabetic rats *

\begin{tabular}{lllllc} 
Treatment period & $\begin{array}{l}\text { Normal } \\
\text { control }\end{array}$ & $\begin{array}{l}\text { Diabetic } \\
\text { control }\end{array}$ & Diabetic + & \multicolumn{2}{c}{ Diabetic + A. wilkesiana extract at a dose } \\
\cline { 5 - 7 } & $14.2 \pm 0.54$ & $11.1 \pm 0.34$ & $10.9 \pm 0.29$ & $11.4 \pm 0.32$ & $11.0 \pm 0.42$ \\
\hline Zero time & $14.8 \pm 0.43$ & $10.6 \pm 0.44$ & $11.1 \pm 0.31$ & $11.9 \pm 0.43$ & $12.3 \pm 0.35$ \\
10 days & $13.9 \pm 0.65$ & $10.9 \pm 0.34$ & $11.7 \pm 0.42$ & $12.8 \pm 0.54$ & $13.0 \pm 0.45$ \\
20 days & $15.0 \pm 0.64$ & $10.3 \pm 0.31$ & $12.5 \pm 0.53$ & $13.1 \pm 0.63$ & $13.0 \pm 0.54$ \\
30 days & & &
\end{tabular}

* The values are mean \pm SD of 6 rats in each group.

At the same time, a $87 \%$, raising in the percentage of serum HDL-C has been achieved when diabetic rats administrated with the dose $40 \mathrm{mg} / 100 \mathrm{~g} \mathrm{~b}$. wt., while treated diabetic rats with aqueous $A$. wilkesiana leaves extract have a moderate effect in increasing HDL-C value which reached 55, 46 and 66\% by using the doses 10,20 and $30 \mathrm{mg} / 100 \mathrm{~g} \mathrm{~b}$. wt., respectively [28]. From the same table, it could be revealed that all doses of methanolic $A$. wilkesiana leaves extract caused a decrease in serum LDL-C and VLDL-C which became 65 and $43 \%$ after 30 days at a dose of $40 \mathrm{mg} / 100 \mathrm{~g} \mathrm{~b}$. wt. respectively, compared with diabetic control rats, indicating the likely cardioprotective effect of the extract at this dose. These decreased values of both LDL-C and VLDL-C clarified that the methanolic extract of $A$. wilkesiana was more effective than aqueous one which realized a reduction of LDL-C and VLDL-C in 10 and 24\%, respectively [28]. Moreover, the study of Odoh et al., [32] indicated that a significant reduction $(\mathrm{p}<0.05)$ in serum total cholesterol and triacylglycerol levels of $50 \%$ and $58 \%$, respectively, was observed for the dose $200 \mathrm{mg} / \mathrm{kg} \mathrm{b}$. wt. of methanolic $A$. wilkesiana root extract in alloxan-induced diabetic rats. The beneficial effects of methanolic $A$. wilkesiana leaves extract on lipid profile of diabetic rats could be related to the insulinotropic effect or the insulin secretagogue activity of this extract by its components, especially flavonoids, which significantly increased LDL receptor mRNA levels, which, in turn, increase hepatic uptake and degradation of LDL causing a decrease in serum LDL levels, as well as its caroteinoides, which are thought to act mainly as antioxidants [39].

\subsection{Effect of crude methanolic leaves extracts of Acalypha wilkesiana on atherogenic indices}

Atherogenic indices are powerful indicators of the risk of heart disease. The higher values of atherogenic indices are a sign of the higher risk of developing cardiovascular diseases [40]. On the other hand, low atherogenic indices pointed to the protection against coronary heart diseases [41].

Clinical findings in Table 6 show the effect of crude methanolic $A$. wilkesiana leaves extract on atherogenic indices in diabetic rats. It could be concluded that no significance differences in both cardiac risk ratio and atherogenic coefficient between normal rats and diabetic rats administrated with the extract after 30 days. In addition, the results for atherogenic index of plasma appeared no significant differences in both normal and treated diabetic rats at all experimental periods. Our consequences for atherogenic indices were in the same line with those obtained by Ikewuchi et al., [28] who accomplished that no significant differences in the atherogenic indices of the A. wilkesiana treated groups compared with control, except the atherogenic index of plasma which was significantly lower. In addition, these portends reductions of cardiovascular risk, according to clinical data as a caused by raising of HDL-C concentration in plasma [42]. Furthermore, treated diabetic rats showed decrease in atherogenic index and increase in percentage of protection against atherogenicity. Our data reported that a decrease in atherogenic index is due to an increase in HDL-C levels after the treatment with plant extract. HDL-C is known to play an important role in the transport of cholesterol from peripheral cells to the liver by a pathway termed reverse cholesterol transport, and is considered to be a cardio protective lipid. The existence of negative correlation between HDL-C and atherosclerosis resulted in improvement in the percentage of protection against atherogenicity in STZ-induced diabetic treated rats [43]. Thus, the antihyperlipidemic effect of methanolic $A$. wilkesiana leaves extract could play a protective role against the development of atherosclerosis and cardiovascular complications in diabetes mellitus.

\subsection{Haematological parameters (complete blood count)}

The complete blood count (CBC) is used as a broad screening test to check for such disorders as anemia, infection and many other diseases. It is actually a panel of tests that examines different parts of the blood, which play an important role in metabolism and important indicators of health in both human or animals [44]. The complete blood count (CBC) includes the following tests.

\subsubsection{Hemoglobin (Hb)}

Hemoglobin $(\mathrm{Hb})$ was measured to detect anemia and its severity. This is one of those tests that will vary in reference ranges, although it is fair to say that values around or less than $10 \mathrm{~g} / \mathrm{dL}$ are usually seen in patients with some signs or symptoms of anemia such as shortness of breath or fatigue and pallor [45]. Our findings in Table 7 show a decrease in hemoglobin levels from 14.2 to $11.1 \mathrm{~g} / \mathrm{dL}$ by the injection with STZ to induce diabetes mellitus. Then, the oral administration of methanloic $A$. wilkesiana leaves extract in doses 10, 20 and $40 \mathrm{mg} / 100 \mathrm{~g} \mathrm{~b}$. wt. confirmed a non-significant dose-dependent increase in hemoglobin levels to reach $13.1,13.6$ and $15.0 \mathrm{~g} / \mathrm{dL}$, respectively at the end of the experimental period. Therefore, the bioactive components in methanloic extract healing effect on disorders of anemia, such as shortness of breath and pallor. 
Table 8. Effect of treatment of crude methanol leaves extract of Acalypha wilkesiana on levels of RBC $\left(10^{6} / \mu \mathrm{L}\right)$ and RBC indices in diabetic rats *

\begin{tabular}{|c|c|c|c|c|c|c|c|c|}
\hline & & \multirow{2}{*}{$\begin{array}{l}\text { Treatment } \\
\text { period }\end{array}$} & \multirow{2}{*}{$\begin{array}{l}\text { Normal } \\
\text { control }\end{array}$} & \multirow{2}{*}{$\begin{array}{l}\text { Diabetic } \\
\text { control }\end{array}$} & \multirow{2}{*}{$\begin{array}{l}\text { Diabetic + } \\
\text { metformin }\end{array}$} & \multicolumn{3}{|c|}{ Diabetic $+A$. wilkesiana extract ata dose: } \\
\hline & & & & & & $10 \mathrm{mg} / 100 \mathrm{~g}$ b. wt. & $20 \mathrm{mg} / 100 \mathrm{~g}$ b. wt. & $40 \mathrm{mg} / 100 \mathrm{~g}$ b. wt \\
\hline \multirow{2}{*}{\multicolumn{2}{|c|}{$\operatorname{RBC}\left(10^{6} / \mu \mathrm{L}\right)$}} & Zero time & $8.33 \pm 0.24$ & $6.15 \pm 0.17$ & $5.93 \pm 0.14$ & $6.69 \pm 0.21$ & $6.43 \pm 0.23$ & $6.83 \pm 0.30$ \\
\hline & & 30 days & $9.01 \pm 0.32$ & $5.92 \pm 0.15$ a & $7.88 \pm 0.27$ & $8.02 \pm 0.34$ & $8.29 \pm 0.25$ & $8.69 \pm 0.19$ \\
\hline \multirow{2}{*}{\multicolumn{2}{|c|}{ HCT (\%) }} & Zero time & $46.9 \pm 1.57$ & $35.2 \pm 0.98$ a & $36.2 \pm 1.11$ a & $35.2 \pm 1.04 \mathrm{a}$ & $37.3 \pm 1.17$ a & $37.7 \pm 1.14^{a}$ \\
\hline & & 30 days & $44.2 \pm 1.32$ & $30.0 \pm 0.89$ a & $39.6 \pm 1.13^{\mathrm{a}, \mathrm{b}}$ & $43.7 \pm 1.36 \mathrm{~b}, \mathrm{c}$ & $44.7 \pm 1.21$ b,c & $45.1 \pm 1.54$ b,c \\
\hline \multirow{2}{*}{\multicolumn{2}{|c|}{$\approx \overline{\mathrm{MCV}\left(\mu \mathrm{m}^{3}\right)}$}} & Zero time & $69 \pm 2.09$ & $36 \pm 1.14^{\text {a }}$ & $39 \pm 1.11 \mathrm{a}$ & $31 \pm 0.88 \mathrm{a}, \mathrm{c}$ & $38 \pm 1.21^{\mathrm{a}}$ & $33 \pm 0.99$ a,c \\
\hline & & 30 days & $70 \pm 2.31$ & $33 \pm 1.11^{a}$ & $51 \pm 1.45 \mathrm{a}, \mathrm{b}$ & $67 \pm 2.01 \mathrm{~b}, \mathrm{c}$ & $68 \pm 2.14$ b,c & $69 \pm 1.99 \mathrm{~b}, \mathrm{c}$ \\
\hline \multirow{2}{*}{\multicolumn{2}{|c|}{$\overline{\mathrm{MCH}(\mathrm{pg})}$}} & Zero time & $20.7 \pm 0.77$ & $14.4 \pm 0.33^{\text {a }}$ & $13.6 \pm 0.32^{\mathrm{a}}$ & $14.3 \pm 0.44^{\text {a }}$ & $14.8 \pm 0.23^{a}$ & $15.2 \pm 0.42^{\mathrm{a}}$ \\
\hline & & 30 days & $23.7 \pm 0.87$ & $13.3 \pm 0.27$ a & $16.9 \pm 0.32$ & $20.0 \pm 0.76^{a, b, c}$ & $20.4 \pm 0.87 a, b, c$ & $20.8 \pm 0.63 a, b, c$ \\
\hline \multirow[t]{4}{*}{ 胥 } & $\overline{\mathrm{MCHC}}(\mathrm{g} / \mathrm{dL})$ & Zero time & $36.4 \pm 1.21$ & $22.7 \pm 0.76^{a}$ & $23.1 \pm 0.87 \mathrm{a}$ & $26.2 \pm 0.45^{\mathrm{a}}$ & $25.3 \pm 0.54^{\mathrm{a}}$ & $25.7 \pm 0.74^{\mathrm{a}}$ \\
\hline & & 30 days & $36.1 \pm 1.14$ & $20.2 \pm 0.77$ a & $27.0 \pm 0.87 \mathrm{a}, \mathrm{b}$ & $34.0 \pm 1.21 \mathrm{~b}, \mathrm{c}$ & $36.2 \pm 1.13 b, c$ & $36.6 \pm 1.14 b, c$ \\
\hline & RDW (\%) & Zero time & $20.7 \pm 0.64$ & $12.7 \pm 0.32$ a & $12.6 \pm 0.24^{a}$ & $13.0 \pm 0.24^{a}$ & $12.9 \pm 0.35^{\text {a }}$ & $13.3 \pm 0.32^{\text {a }}$ \\
\hline & & 30 days & $20.6 \pm 0.55$ & $13.1 \pm 0.28$ a & $16.4 \pm 0.35$ a & $16.2 \pm 0.36$ a & $17.9 \pm 0.35$ a & $18.3 \pm 0.43 \mathrm{~b}$ \\
\hline
\end{tabular}

* The values are mean \pm SD of 6 rats in each group.

Significantly different from normal control at $\mathrm{p}<0.05$.

b Significantly different from diabetic control at $\mathrm{p}<0.05$.

c Significantly different from diabetic+metformin at $\mathrm{p}<0.05$.

Table 9. Effect of treatment of crude methanolic leaves extract of Acalypha wilkesiana on levels of Plt ( $\left.10^{3} / \mu \mathrm{L}\right)$ and Plt indices in diabetic rats *.

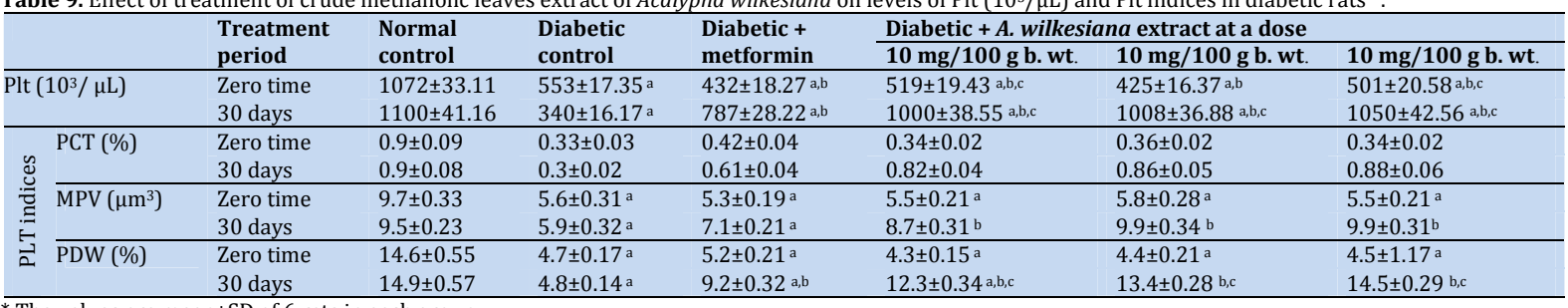

The values are mean \pm SD of 6 rats in each group.

Significantly different from normal control at $\mathrm{p}<0.05$.

Significantly different from diabetic control at $\mathrm{p}<0.05$

c Significantly different from diabetic+metformin at $\mathrm{p}<0.05$.

These results for hemoglobin levels were not agreed with those obtained by Ikewuchi et al., [28] who mentioned that no significant differences between normal and treated rats with aqueous $A$. wilkesiana leaves extract. Thus, extraction of bioactive compounds with methanol was more effective than water to cure symptoms accomplished with hemoglobin decline caused by diabetes mellitus.

\subsubsection{Red blood cells (RBC)}

The count of the actual number of red blood cells (RBC) per volume of blood. Both increase and decrease can point to abnormal conditions. Decreased count of RBC indices to anemia, while increasing count of RBC in the company of fluid loss indices to diarrhea, dehydration and burns [44].

Haematological results in Table 8 illustrate decrease in RBC count from 8.33 to $6.15 \times 10^{6} / \mu \mathrm{L}$ by the injection of rats with STZ to induce diabetes. Then, methanloic leaves extract of $A$. wilkesiana in doses 10,20 and $40 \mathrm{mg} / 100 \mathrm{~g} \mathrm{~b}$. wt. caused an increase in RBC reckon to reach $8.02,8.29$ and $8.69 \times 10^{6} / \mu \mathrm{L}$, respectively after 30 days. From the same table, it could be noticed that RBC indices (HTC, MCV, MCH, MCHC and RDW) were reduced by the injection with streptozocin. Afterward, $\mathrm{RBC}$ indices were gradually increased to almost the normal control rat's values by treatment with $A$. wilkesiana leaves extract. On the contrary, Ikewuchi et al., [28] found no significant differences between normal and treated rats with aqueous A. wilkesiana leaves extract for both RBCs count and RBC indices. This gives an indication that the methanloic $A$. wilkesiana leaves extract may contain some phytochemicals that can stimulate the formation or secretion of erythropoietin in the stem cells of the animals. Erythropoietin is a glycoprotein hormone which stimulates stem cells in the bone marrow to produce red blood cells [46]. The stimulation of this hormone enhances rapid synthesis of RBC which is supported by the improved level of MCH and MCHC [47]. Moreover, Table 1 indicates the presence of flavonoids, tannins, phenols and flavonols in methanloic A. wilkesiana leaves extract. These compounds have been reported to possess strong antioxidant capacity, therefore, could inhibit the peroxidation of polyunsaturated fatty acids in the cell membrane and haemolysis of red blood cells in the diabetic animals.

\subsubsection{Platelets (PIt)}

Platelets (Plt) are produced within the vascular channels (sinusoids) of the bone marrow by the fragmentation of the protruding cytoplasm of large bone marrow cells known as megakaryocytes. Platelets count and its indices (PCT, MPV and PDW) levels were reduced to reach about $50 \%$ of these values in normal rats when streptozocin was used to induce diabetes mellitus. Then, the oral administration of methanoic $A$. wilkesiana leaves extract established dose-dependent increase in platelet counts and its indices to achieve the highest percentage levels (about 90\%) compared with diabetic rats at a dose of $40 \mathrm{mg} / 100 \mathrm{~b}$. wt. at the end of the experimental period as shown in Table 9.

Our findings were in accordance with those obtained by Ikewuchi et al., [28] who calculated the increasing percentages of platelet counts to reach about 94,57 and $31 \%$ of treated diabetic rats with aqueous $A$. wilkesiana leaves extract at doses 10,20 and $30 \mathrm{mg} / 100 \mathrm{~g} \mathrm{~b}$. wt., respectively. These increasing in platelets count and its indices imply the increase in clotting which protect against bleeding and increase insulin resistance as the cause of predisposition to adverse cardiovascular events. Taniguchi et al., [48] reported that increased platelets count may independently predict insulin resistance among non obese type 2 diabetes mellitus patients. This effect indicated the ability of the methanoic $A$. wilkesiana leaves extract to stimulate the biosynthesis of clotting factors due to the presence of active compounds that might help to precipitate blood coagulation or clotting, especially during severe bleeding or haemorrhage [49]. 
Table 10. Effect of treatment of crude methanolic leaves extract of Acalypha wilkesiana on levels of WBC $\left(10^{3} / \mu \mathrm{L}\right)$ and WBC differential in diabetic rats *.

\begin{tabular}{|c|c|c|c|c|c|c|c|c|}
\hline & \multirow{2}{*}{$\begin{array}{l}\text { Treatment } \\
\text { period }\end{array}$} & \multirow{2}{*}{$\begin{array}{l}\text { Normal } \\
\text { control }\end{array}$} & \multirow{2}{*}{$\begin{array}{l}\text { Diabetic } \\
\text { control }\end{array}$} & \multirow{2}{*}{$\begin{array}{l}\text { Diabetic + } \\
\text { metformin }\end{array}$} & \multicolumn{3}{|c|}{ Diabetic $+A$. wilkesiana extract at adose } \\
\hline & & & & & & $10 \mathrm{mg} / 100 \mathrm{~g}$ b. wt & $10 \mathrm{mg} / 100 \mathrm{~g} \mathrm{~b} . \mathrm{wt}$ & $10 \mathrm{mg} / 100 \mathrm{~g}$ b. wt \\
\hline \multirow{2}{*}{\multicolumn{2}{|c|}{$\mathrm{WBC}\left(10^{3} / \mu \mathrm{L}\right)$}} & Zero time & $6.5 \pm 0.43^{d}$ & $11.5 \pm 0.66^{a}$ & $12.1 \pm 0.65^{a}$ & $11.7 \pm 0.56^{\text {a }}$ & $11.9 \pm 0.54^{a}$ & $11.5 \pm 0.55$ a \\
\hline & & 30 days & $5.9 \pm 0.21 \mathrm{~d}$ & $12.0 \pm 0.45$ a & $9.2 \pm 0.32 \mathrm{a}, \mathrm{b}$ & $7.3 \pm 0.43 b$ & $6.6 \pm 0.31 \mathrm{~b}, \mathrm{c}$ & $6.5 \pm 0.31 \mathrm{~b}, \mathrm{c}$ \\
\hline \multirow{6}{*}{ 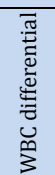 } & LYM (\%) & Zero time & $58.4 \pm 2.13^{c}$ & $66.1 \pm 2.43^{a}$ & $69.4 \pm 2.22^{a}$ & $68.5 \pm 2.87 a$ & $67.3 \pm 2.76^{a}$ & $67.0 \pm 2.42^{a}$ \\
\hline & & 30 days & $51.7 \pm 2.09 \mathrm{~d}$ & $75.3 \pm 2.54$ a & $60.1 \pm 1.89$ & $51.5 \pm 2.03$ & $53.1 \pm 2.11 b, c$ & $52.7 \pm 1.99 \mathrm{~b}, \mathrm{c}$ \\
\hline & MON (\%) & Zero time & $1.3 \pm 0.02^{\mathrm{a}}$ & $1.9 \pm 0.09 \mathrm{a}$ & $1.8 \pm 0.08$ & $1.1 \pm 0.07 \mathrm{~b}$ & $1.0 \pm 0.08^{\mathrm{b}}$ & $1.2 \pm 0.08^{b}$ \\
\hline & & 30 days & $1.9 \pm 0.03$ a & $1.3 \pm 0.09$ a & $1.0 \pm 0.09$ a & $1.1 \pm 0.01 \mathrm{a}$ & $1.8 \pm 0.31^{\mathrm{c}}$ & $1.7 \pm 0.31 \mathrm{c}$ \\
\hline & GRA (\%) & Zero time & $40.3 \pm 0.25^{c}$ & $32.0 \pm 0.31$ a & $28.8 \pm 0.17$ a,b & $30.4 \pm 0.21^{a, c}$ & $31.7 \pm 0.19$ a,c & $31.8 \pm 0.21 \mathrm{a}, \mathrm{c}$ \\
\hline & & 30 days & $46.4 \pm 1.11^{\text {a }}$ & $23.4 \pm 0.76^{a}$ & $38.9 \pm 0.65 \mathrm{a}, \mathrm{b}$ & $48.4 \pm 0.45 \mathrm{~b}, \mathrm{c}$ & $45.9 \pm 0.64$ b,c & $45.6 \pm 0.65 \mathrm{~b}, \mathrm{c}$ \\
\hline
\end{tabular}

* The values are mean \pm SD of 6 rats in each group.

a Significantly different from normal control at $\mathrm{p}<0.05$.

b Significantly different from diabetic control at $p<0.05$.

c Significantly different from diabetic + metformin at $\mathrm{p}<0.05$.

\subsubsection{White blood cells (WBC)}

White blood cells (WBC) were primarily formed in the bone marrow and may also be produced in organs of the lymphatic system such as spleen, thymus and lymph nodes. They serve to fight off infections and protect the body from diseases. This test serves to monitor diseases progression and/or response to chemotherapy. Moreover, the differential divided the various types of white blood cells based on size distribution. The differential is done to evaluate the body's capacity to resist and overcome infection [45]. Quantifiable findings in Table 10 explain the effect of streptozocin injection of white blood cells and its indices (LYM, MON and GRA which include neutrophils, eosinophils, and basophils). Drug poisoning is one of the main causes of raising white blood cell count, which plays important roles in the destabilization of coronary artery plaques at the onset of acute coronary syndrome [50]. However, an elevated white blood cell count in peripheral blood is a known risk factor of coronary artery disease [51]. Thus, the observed higher white blood cell count for diabetic rats suggestion the protection against onset of acute coronary syndrome and the increased risk of coronary artery disease. On the other hand, the white blood cell counts and its related indices were significantly restored to near normal after methanolic $A$. wilkesiana leaves extract administration at doses 20 and 40 $\mathrm{mg} / 100 \mathrm{~g} \mathrm{~b}$. wt. The presence of some phytochemicals in the $A$. wilkesiana leaves extract with the ability to stimulate the production of white blood count and its differentials could be responsible for the observed results in the treated diabetic rats. This observation of increasing levels of these parameters by $A$. wilkesiana extract suggests that the principal function of phagocytes, which is to defend against invading microorganisms by ingesting and destroying them, thus contributing to cellular inflammatory processes of the animals, will be enhanced [52].

\section{Conclusion}

In conclusion, this investigation revealed the presence of pharmacologically active compounds in the methanoilc extract of Acalypha wilkesiana leaves. This extract had hypoglycemic activities and positively affected on the hematopoietic system, the integrity of liver and kidney functions and improved the lipid profile as a cardioprotective agent for STZ treated diabetic rats. Furthermore, extract had no deleterious effect on hemoglobin or red blood cell morphology. All of these highlights of methanolic Acalypha wilkesiana leaves extract support its uses as a potential source of discovery for new therapeutic agents for health care and management of diabetes mellitus and its complications.

\section{References}

[1]. Caughron, K. F.; Smith, E. L. South Med. J. 2002, 95(1), 35-49.

[2]. Lebovitz, H. E. J. Clin. Psychiatry 2001, 62(27), 5-9.

[3]. Kanter, M. Tip Aras. Der. 2009, 7(2), 64-70.
[4]. Vessal, M.; Hemmatia, M.; Vasei, M. Comp. Biochem. Physiol. C Toxicol. Pharmaco. 2003, 135(3), 357-364.

[5]. Venkatesh, S.; Reddy, G. D.; Reddy, B. M.; Ramesh, M.; Apparao, A. V. N. Fitoterapia 2003, 74(3), 274-277.

[6]. Chan, C. H.; Ngoh G. C.; Yusoff, R. Pharmacogn. Rev. 2012, 6(11), 22-28

[7]. Ogundaini, A. O. An Inaugural Lecture Delivered at Oduduwa Hall, Obafemi Awolowo University, Ile-Ife, Nigeria. Inaugural Lecture Series 176, OAU Press Limited, Ile-Ife, Nigeria, pp. 12-15, 2005.

[8]. Akinyemi, K. 0.; Oluwaans, 0. K.; Omomigbehin, E. O. Afr. J. Tradit Compl. Altern. Med. 2006, 3(4), 13-22.

[9]. Ikewuchi, J. C. Asian Pac. J. Trop. Med. 2013, 6(1), 37-42.

[10]. Lim, S. W.; Loh, H. S.; Ting, K. N.; Bradshaw, T. D.; Zeenathul, N. A. Int. J. Biosci. Biochem. Bioinforma. 2013, 3(4), 335-340.

[11]. Udobang, J. A.; Nwafor, P. A.; Okokon, J. E. J. Ethnopharmacol. 2010 127(2), 373-378.

[12]. Rahmatullah, M.; Das, A. K.; Mollik, M. A. H.; Jahan, R.; Khan, M.; Rahman, T.; Chowdhury, M. H. Am. -Eurasian J. Sustain. Agric. 2009, $3(4), 881-888$.

[13]. Raj, J.; Singh, K. P. Acalypha indica. CCRH Q. Bull. 2000, 22, 1-6.

[14]. Nahrstedt, A.; Hungeling, M.; Petereit, F. Fitoterapia 2006, 77, 484 486.

[15]. Goupy, P.; Hugues, M.; Boivin, P.; Amiot, M. J. J. Sci. Food Agric. 1999, $79,1625-1634$.

[16]. Ghasemi, M.; Sadeghipour, H.; Asadi, S.; Dehpour, A. R. Life Sci. 2007, 81(12), 960-969.

[17]. Orhan, N.; Aslan, M.; Orhan, D. D.; Ergun, F.; Yesilada, E. Ethnopharmacol. 2006, 108, 280-286.

[18]. Trinder, P. Ann. Clin. Biochem. 1969, 6, 24-27.

[19]. Reitman, S.; Frankel, S. Amer. J. Clin. Path. 1957, 28(1), 56-63.

[20]. Larsen, K. Clin. Chim. Acta 1972, 41, 209-217.

[21]. Fawcett, J. K.; Scott, J. E. J. Clin. Path. 1960, 13, 156-159.

[22]. Fossati, P.; Prencipe, L. Clin. Chem. 1982, 28, 2077-2080.

[23]. Richmond, W. Clin. Chem. 1973, 19, 1350-1356.

[24]. Lopes-Virella, M. F.; Stone, P.; Ellis, S.; Colwell, J. A. Clin. Chem. 1977, $23,882-884$.

[25]. Friedewald, W.; Levy, R.; Fredrickson, D. Clin. Chem. 1972, 18, 499502.

[26]. Ikewuchi, J. C.; Ikewuchi, C. C. Biokemistri 2009, 21, 71-77.

[27]. Nakul-Aquaronne, D.; Sudaka-Sammarcelli, I.; Ferrero-Vacher, C.; Starck, B.; Bayle J. J. Clin. Lab. Anal. 2003, 17, 113-123.

[28]. Ikewuchi, J. C.; Onyeike, E. N.; Uwakwe, A. A.; Ikewuchi, C. C. J. Ethnopharmacol. 2011, 137(3), 1415-1424.

[29]. Basu, S. K.; Thomas, J. E.; Acharya, S. N. Aust. J. Basic Appl. Sci. 2007, 1(4), 637-649.

[30]. Lenzen, S. Diabetologia 2008, 51(2), 216-26.

[31]. Al-Attar, A. M. Am. Med. J. 2010, 1(1), 51-58.

[32]. Odoh, U. E.; Ndubuokwu, R. I.; Inyagha, S. I.; Ezejiofor, M. Planta Med. 2013, 79-SL10, DOI: 10.1055/s-0033-1351836.

[33]. Esmaeili, M. A. and Yazdanparast, R. J. Ethnopharmacol. 2004, 95, 27 30.

[34]. Kim, J. S.; Ju, J. B.; Choi, C. W.; Kim, S. C. Am. J. Biochem. Biotechnol. 2006, 2, 154-160.

[35]. Mahmoud, H. I.; Elrab, Gad, S. M. G.; Khalil, A. F. Ismael, S. M. Eur. J. Chem. 2014, 5(1), 65-72.

[36]. Gokce, G.; Haznedaroglu, Z. M. J. Ethnopharmacol. 2008, 115, 122-130.

[37]. Shen, G. X. Curr. Pharmaceut. Anal. 2007, 3, 17-24.

[38]. Fernandez, M. D.; Garcia, J. L.; Garcia, F. D. N. Engl. J. Med. 2001, 334, 1398-1399.

[39]. Wilcox L. J.; Borradaile, N. M.; de Dreu, L. E.; Huff, M. W. J. Lipid Res. 2001, 42, 725-34.

[40]. Dobiasova, M. Clin. Chem. 2004, 50, 1113-1115.

[41]. Usoro, C. A. O.; Adikwuru, C. C.; Usoro, I. N.; Nsonwu, A. C. Pak. J. Nut. 2006, 5, 79-82.

[42]. Assmann, G.; Gotto Jr. A. M. Circulation 2004, 109, 8-14.

[43]. Gebhardt, R. J. Pharmacol. Exp. Ther. 1998, 286, 1122-1128.

[44]. Bain, B. J. Blood Cells (A Practical Guide), $4^{\text {th }}$ edition. Blackwell Publishing Ltd. 2006. 
[45]. Bain, B. J. A Beginner's Guide to Blood Cells, $2^{\text {nd }}$ edition. Blackwell Publishing Ltd. 2004

[46]. Ohlsson, A.; Aher, S. M. Cochrane Database Syst Rev. 2006, 3:CD004863. DOI: 10.1002/14651858.CD004863.pub3

[47]. Abu-Zaiton AS. Pak. J. Biol. Sci. 2010, 13(2), 97-100.

[48]. Taniguchi, A.; Fukushima, M.; Seino, Y.; Sakai, M.; Yoshii, S.; Nagasaka, S.; Yamauchi, I.; Okumura, T.; Nin, K.; Tokuyama, K.; Yamadori, N.; Ogura, M.; Kuroe, A.; Nakai, Y. Metabolism Clin. Exp. 2003, 52, 12461249.

[49]. Dahlback, B. Blood 2008, 112(1), 19-27.

50]. Libby, P. Circulation 2001, 104, 365-372.

[51]. Takeda, Y.; Suzuki, S.; Fukutomi, T.; Kondo, H.; Sugiura, M.; Suzumura, H.; Murasaki, G.; Okutani, H.; Itoh, M. Jpn. Heart J. 2003, 44, 201-211.

[52]. Adedapo, A. A.; Adegbayibi, A. Y.; Emikpe, B. O. Phytotherapy Res. 2005, 19, 971-976. 